\title{
A KATONAI KÖZLEKEDÉSI TÁMOGATÁS VASÚTFÖLDRAJZI ALAPÚ VIZSGÁLATA
}

\author{
LÉVAI ZSOLT \\ INVESTIGATION OF THE MILITARY TRANSPORTATION SUPPORT SYSTEM \\ BASED ON RAIL-GEOGRAPHICAL ASPECTS
}

\begin{abstract}
Trains running on rails are the integral part of the transport system and such as, they can be classified as elements of the transportation support system in the military logistics. The volume of the military transport-movement tasks is constantly increasing, also due to allied obligations. Because of the adequate transport capacity of the rail-sector, as well as its more beneficial environmental characteristic, it is worth examining how the geographical conditions enable the sub-sector to complete the increasing military transportation and transportation support tasks. My article deals with this analysis through military, social and physical geographic approaches.
\end{abstract}

Keywords: military geography, transportation geography, railway geography, military logistics, transportation support, substitutability

\section{Bevezetés}

A vasút a szállítási módok egyik eszközeként jelentős szerepet vállal mind a személy-, mind az áruszállítás terén, ezért e közlekedési alágazat szerepe nemzetgazdasági jelentőségú. Környezetbarátabb szállítási mód, mint a közúti vagy a légi közlekedés, ezáltal a fenntartható fejlődés egyik záloga lehet. A vasúti közlekedés ugyanakkor - mivel a hadsereg mozgási-szállítási szükségletének kielégítése egyike az elsőrangú szempontoknak közremúködik Magyarország katonai védelmében is. A mozgásokat a katonai logisztikai támogatás rendszere hivatott levezetni, aminek feladata a katonai jellegú anyagi, egészségügyi, közlekedési és elhelyezési szükségletek kielégítése (BÁTHY S. 2013). A közlekedés, azaz a mozgatások és szállítások lebonyolítása a katonai közlekedési támogatás feladata. A NATO-tagságból adódó és a szervezet által elvárt közlekedési teljesítmények növekedése (PETE Sz. 2019) okán vizsgálni kell, hogy a többletfeladatokat a vasúti közlekedési alágazat le tudja-e bonyolítani. Jelen tanulmány a vasúti közlekedés és a katonai közlekedési támogatás kapcsolatát vizsgálja a vasúti közlekedési rendszer földrajzi megközelítésén keresztül, illetve választ ad az egyes vasúti infrastruktúra-elemek, mint kritikus közlekedéshálózati rendszerelemek helyettesíthetőségének földrajzi kérdéseire.

\section{Katonai közlekedési támogatás}

\section{A katonai közlekedési támogatás logisztikai megközelítése}

A logisztika ma már életünk minden területén, s ennek megfelelően a honvédelemben is jelen van. A hadtudományi kutatások bizonyítják, hogy a logisztika tudományának katonai gyökerei is vannak. A napóleoni háborúk svájci-francia hadvezére, Henri Jomini a logisztikát a hadtudomány harmadik ágának nevezte (BÁTHY S. 2013). KRESS, M. (2016) a katonai logisztika három alapvető feladatát különbözteti meg: 
- a szükséges erőforrások biztosítása a harctéren;

- a csapatok és eróforrások mozgatása;

- erőforrások szállítása a hátországból és elosztása a harcoló alakulatok között (utánpótlási szállítások).

A felsorolásból látható, hogy a közlekedés a logisztika teljes vertikumában jelen van. A rendszer megfelelő múködése biztosítja a katonai feladatok végrehajthatóságát, ami elengedhetetlen feltétele az ország védelmi képességének. A logisztikai feladatok végrehajtása és az ehhez szükséges szállítási kapacitás (infrastruktúra és szállítóeszköz) biztosítása a katonai közlekedési támogatási rendszer feladata.

Ugyancsak nélkülözhetetlen a vasúti közlekedés az ellátási láncok múködtetésében. A logisztikai rendszerekre épülő ellátási láncok közlekedési elemeinek kiesése zavart okoz például az élelmiszerellátásban, ami szintén országos méretú problémákhoz vezethet. Hasonló a helyzet az energiaszektorban is. Itt ráadásul interdependenciáról azaz kölcsönös függésről beszélhetünk, például a villamos vasútüzem energiaigényéről, amit a villamos mozdonyok vontatta tehervonatok szénszállítmányaiból elégítenek ki.

\section{A katonai közlekedési támogatás földrajzi megközelítése}

A fentiekben meghatározott katonai szállítási-mozgási feladatok a térben történnek, és mint ilyenek, hatással van rájuk a földrajzi környezet. Ezért a feladatok elvégezhetőségének vizsgálata földrajzi szempontból is feltétlenül szükséges. A földrajztudomány katonai szempontú megközelítésével a katonaföldrajz foglalkozik. A legújabb, 2019-ben kiadott Hadtudományi lexikon meghatározása szerint a katonaföldrajz a had- és a földrajztudomány interdiszciplináris területe, amely általános, regionális és ágazati területekre tagolódik (SiPOSNÉ K. K.2019). Jelen tanulmány szempontjából, a regionális katonaföldrajz vonalán tovább haladva, a Hadtudományi lexikon ide sorolja a védelemföldrajzot és a katonai országismeretet.

A közlekedési támogatás rendszerének földrajzi megközelítésekor a társadalomföldrajz egyik ágaként definiált közlekedésföldrajz meghatározásából lehet kiindulni. A szakterület feltárja a közlekedési ágazat gazdaságföldrajzi jellemzőit, illetve a természetföldrajzi adottságokkal való kapcsolatát, valamint foglalkozik a közlekedési hálózatok földrajzi kérdéseivel.

E tanulmányban a katonai védelemgazdaság egyik fontos elemét, a közlekedési támogatást vizsgálom meg földrajzi szempontok alapján.

Az ország megfelelő védelmi felkészítése megköveteli, hogy az ennek érdekében végzett feladatok maradéktalanul teljesíthetők legyenek. A szállítási feladatok tekintetében ez csak akkor lehetséges, ha tisztában vagyunk az egyes közlekedési ágak nyújtotta lehetőségekkel. Ebbe beletartozik a közlekedési módok előbb részletezett földrajzi elemzése is, illetve annak kutatása, hogy a szállítási-mozgási feladatok hogyan oszthatók meg optimálisan az egyes közlekedési alágazatok között. A katonai országismeret és hadszíntér-felderítés keretében tisztában kell lenni a vasúti közlekedés szállítási lehetôségeivel, aminek megismeréséhez földrajzi elemzés szükséges. Cikkem ezt az elemzést mutatja be.

\section{A közlekedési támogatás feladatai}

A katonai közlekedési feladatok szervezésének és tervezésének első mozzanata a megfelelő közlekedési mód kiválasztása. A választás elsősorban az útvonal földrajzi viszonyaitól (például a domborzattól, időjárási viszonyoktól), az egyes közlekedési alágazatok rendelkezésre állásától, infrastruktúrájának lehetôségeitől (például a közlekedési pályák 
terhelhetőségétől (tengelyterhelés), a műveletek jellegétől és intenzitásától, valamint a szállítandó erôk összetételétől függ (LÉVAI Zs. 2020). Emellett természetesen még sok egyéb összetevője van a szállítási mód megválasztásának, de ezek elsősorban katonai jellegúek és jelen cikk szempontjából irrelevánsak.

A közlekedési támogatás szakfeladatai az alábbi feladatok köré csoportosíthatók $(\mathrm{MH}$ 2005):

- kijelölés: a közlekedési igények kielégítéséhez szükséges és tartalék-kapacitások képzése;

- felkészítés: közlekedési infrastruktúrák (pályák, jármúvek) katonai múveleti követelmények szerinti felkészítése;

- üzemeltetés: a közlekedési feladatok folyamatos végrehajtása;

- technikai oltalmazás: a közlekedési infrastruktúrák múködóképességének megőrzése;

- helyreállítás: a közlekedési infrastruktúrák rombolása esetén a közlekedés mihamarabbi újraindítására irányuló tevékenység.

A vasúti alágazat nagymennyiségű áru és jelentősebb létszámú személyi állomány nagy távolságra történő szállítására alkalmas. További előnye, hogy egyszerre többféle eszköz és anyag is szállítható a különböző típusú vasúti kocsikban, amelyek egy szerelvénybe sorozhatók, sőt bizonyos szabályok betartása mellett egyszerre szállíthatók az eszközök és a személyi állomány is.

\section{A vasúti közlekedési rendszer múlködésének földrajzi jellemzői}

A katonai közlekedési támogatási szakfeladatok ellátásához szükséges közlekedési alágazat kiválasztásának egyik szempontja az adott szektor földrajzi jellemzőinek ismerete.

Adott vasúthálózat esetében ezek az alábbiak:

- vonali vágányok száma;

- villamosítottság;

- eróátviteli mód;

- pályasebesség;

- nyomtávolság;

- a vonal jellege.

A vonali vágányok számán két állomás között, vasúti közlekedésre használható vágányok számát értjük. Ezek alapján egy-, két-, illetve többvágányú vonalakról és állomásközökről beszélhetünk.

A villamositottság azt jelenti, hogy adott vonalon tudnak-e villamos mozdonyok közlekedni vagy sem. Fontos megjegyezni, hogy az áramfelvétel nem csak a mozdony tetején elhelyezett pantográffal lehetséges, de nagyvasúton a villamos vontatást elsősorban még felsővezetéki rendszer kiépítésével oldják meg.

Erőátviteli mód alapján beszélhetünk adhéziós, fogaskerekú, illetve kötélvontatásról. Adhéziós vontatás esetén a vonóerőt a mozdony kereke és a sín közötti súrlódás adja. Az alkalmazott eróátviteli módot leginkább a terepviszonyok határozzák meg. Magyarországon a földrajzi viszonyok miatt nem szükséges fogaskerekú, illetve kötélpályák kialakítása, ugyanis adhéziós vontatás $25 \%$-es emelkedésig alkalmazható, és hazánkban nincs olyan hegy, ahol ennél meredekebb emelkedésú pályát kellene építeni. Természetesen ez nem azt jelenti, hogy nincs ennél meredekebb emelkedésú vasúti pálya az országban, ahol helyi magasságnyerést vagy pályasüllyesztést kell biztosítani, azonban ezek hossza elenyésző (néhány tíz méter), így azokon a vonatok minimális sebességvesztéssel végig tudnak 
haladni. Az ilyen emelkedőket rohamos emelkedőknek hívjuk (például: városi villamosvonal kivezetése egy aluljáróból). Magyarország egyetlen fogaskerekú vasútja Budapesten található. Kötélpálya a budapesti sikló, libegő, illetve ide sorolhatjuk a sífelvonókat is.

A pályasebességet jelentősen befolyásolja a földrajzi környezet (például a vasútvonal kanyargós folyóvölgyben fut, ahol az alkalmazható sebesség az ívsugarak méreteitől függ), de fordítva is igaz: meghatározott pályasebesség eléréséhez szükség lehet bizonyos mútárgyak (például hidak, alagutak) építésére. Ezek segítenek a sebesség megfelelő szinten tartásában, ugyanakkor építésük jelentős költségekkel jár. Magyarországon viszonylag kevés alagút van és azok is rövidek; a leghosszabb sem éri el az 1000 métert.

Az ország vasútvonalainak jelentős többsége normál nyomtávú (1435 mm), ugyanakkor az ukrán vasúti hálózat széles nyomtávja $(1520 \mathrm{~mm})$ miatt hazánkban is található néhány km-nyi ilyen nyomtávolságú pálya, illetve fonódott szakasz Záhony körzetében. A normál és a széles nyomtáv közötti átjárásra vagy nyomtávváltó berendezést használnak, amely átállítja a vasúti kocsik kerékpárjainál a kerekek távolságát, vagy tengelyátszerelést alkalmaznak: a vagonok kerékpárjait a kocsik felemelése után kicserélik. Ha egyik megoldás sem alkalmazható, akkor a rakományt rakják át a másik nyomtávú kocsiba. E munkához külön átrakó-pályaudvarokat alakítottak ki.

Keskeny nyomtávolságú vasútvonalból sok van Magyarországon. Ezek többségükben gazdasági vagy erdei vasutak; a budapesti a gyermekvasút turisztikai jelentőségú.

A vasútvonalak jellegük szerint lehetnek:

- síkvidéki vonalak: emelkedői kevesebb, mint 7\%o-esek (alföldek, nagyobb folyóvölgyek);

- dombvidéki vonalak: emelkedőik meredeksége 7-15\%;

- hegyvidéki vonalak: emelkedőik meredeksége 16-25\%o (extrém esetben 28-30\%o-es emelkedésú adhéziós vasút is van).

Ha a terep emelkedése nem megfelelő (túl meredek), akkor vonalkifejtéssel (mesterséges úthosszabbítással) lehet a magasságkülönbséget áthidalni.

A vasúti pálya jellege, emelkedési viszonyai a fellépő emelkedési ellenállás hatására jelentősen befolyásolják a vonóeró-szükségletet, ezzel a vonatok terhelését, következésképp vasútvonal átbocsátóképességét.

\section{Vasútföldrajz és katonai közlekedési támogatás}

Ebben a fejezetben a katonai közlekedési támogatási feladatok elvégezhetőségét vizsgálom meg.

\section{Kijelölés}

A katonai mozgások-szállítások elvégezhetósége szempontjából fontos, hogy adott feladatot minden körülmények között el lehessen végezni. Ezért a közlekedési hálózat elemei közül ki kell jelölni azokat az útvonalakat, amelyeken a szállítási feladatok teljesíthetôk. Nincs ez másként a vasút tekintetében sem: meg kell határozni azokat a vasútvonalakat, amelyeken katonai vasúti szállításokat le kell bonyolítani. A szövetségesi feladatokból adódóan ezek többnyire tranzit vasútvonalak, illetve katonai bázisokhoz, repülőterekhez vezetnek. Az útvonalak meghatározásakor a vasút földrajzi jellemzőit a következők szerint javaslom figyelembe venni:

- A vonatforgalom fenntarthatósága érdekében törekedni kell a kétvágányú szakaszok minél nagyobb igénybevételére. 
- Költséghatékonysági megfontolások alapján ugyancsak törekedni kell a villamosított vasútvonalak minél szélesebb körü bevonására.

- Erőátvitel szempontjából csak adhéziós vontatás jöhet szóba.

- A sebesség tekintetében kiválóan használhatók az ismert gráfelméleti modellek: lehetséges ugyanis a sebesség mindkét fizikai összetevőjére optimalizálni a továbbítási útvonalat, azaz meghatározni a távolság-optimumot, illetve az eljutási idő optimumát. A vasútvonalakon engedélyezett sebesség nem egyezik meg a vonatok haladási sebességével (vonatra engedélyezett sebesség). Ez utóbbi függ a mozdony és a vonatba sorozott vasúti kocsik engedélyezett sebességétől, a vontatott tömegtől, illetve a pálya paramétereitől. Ezért nem biztos, hogy minden esetben a legnagyobb sebességgel járható szakaszt is magába foglaló út lesz az optimális.

- A katonai szállítások nagyon kevés kivételtől eltekintve hagyományos személy- és teherkocsikban történnek, így a nyomtávolság kérdésében a már ismertetett módokon kell eljárni. Az Európa nagyobb részén alkalmazott normál nyomtávon (1.ábra) a vonatok minden gond nélkül közlekedhetnek. A teherkocsiknál nem alkalmaznak állítható nyomtávú kerékpárokat, ezért ilyen esetekben a szállított anyagot át kell rakni. Személyi állomány szállításakor elvileg lehetséges lenne nyomtávváltós kocsik

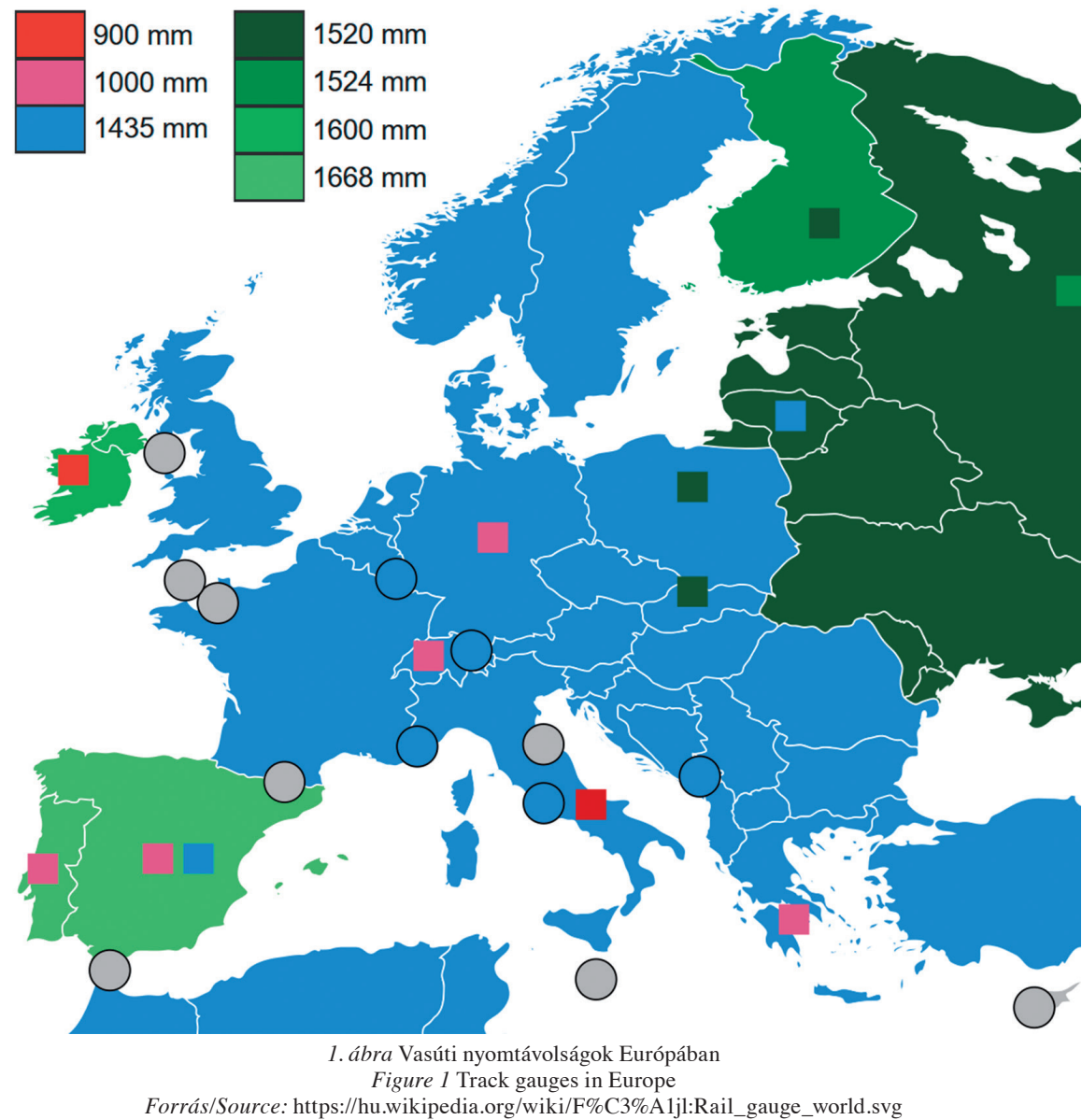


igénybevétele, ugyanakkor ilyenből kevés van, és a vasútvállalatok ezeket inkább kereskedelmi forgalomban használják. Amennyiben a személyi állomány együtt utazik a hadfelszereléssel, akkor az anyagok átrakási ideje alatt ôk is át tudnak szállni, bár ez mindenképpen kellemetlenséggel jár.

A vasútvonal jellege meghatározza a mozdonyok által vontatható elegytömeget. Belátható, hogy minél meredekebb a pálya, annál kisebb tömeg vontatható. Ezért a szállítási útvonalakat úgy kell kijelölni, hogy a vontatható elegytömeg határába beleférjenek a katonai szállítmányok. Természetesen egy-egy esetben előfordulhat, hogy ez nem biztosítható, ilyenkor - ha hosszabb szakaszon áll fenn ez a helyzet - alkalmazható ún. előfogat-mozdony, azaz a vontatás egyszerre két mozdonnyal történik. Kisebb, de meredek szakasz leküzdésére ún. tolómozdonyt alkalmaznak. Ekkor a második mozdony a szerelvény végére áll rá és azt tolva segít a vonat emelkedôre való feljutásában (1. kép).

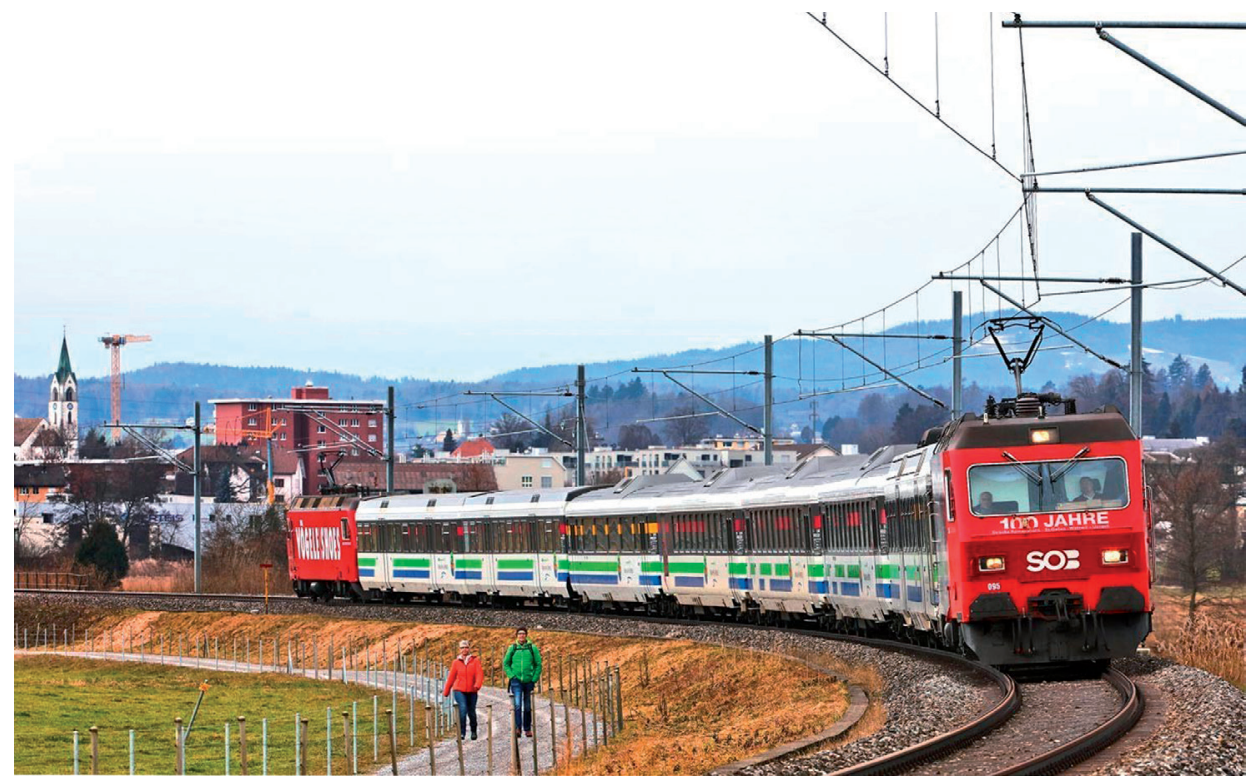

1. kép Tolómozdony alkalmazása (Svájc)

Photo 1 Banking traction unit (Switzerland)

Forrás/Source: https://www.bahnbilder.de/bild/Schweiz Privatbahnen $\sim$ SOB+Sudost-Bahn/993724/die-zuglokomotive-re-456-095-faehrt.html

Fotó/Photo: MORELLi, M.

A katonai szállítási útvonalak kijelölésekor figyelni kell arra, hogy a vasútvonalon a NATO ûrszelvény végig rendelkezésre álljon, azaz egy meghatározott keresztmetszetbe ne nyúljon be tárgy vagy valamilyen természeti képződmény (vagy például egy alagút is megfelelően széles legyen).

\section{Felkészités}

Békeidőben a katonai szállítások előre megszervezhetők és az említett kritériumok alapján útvonaluk kijelölhető. Ugyanakkor a vasúti infrastruktúra kezelőjétől elvárható, hogy a fent meghatározott feltételek döntő többségükben teljesüljenek, azaz a vasúti infrastruktúra-elemek fel legyenek készítve a katonai szállítások okozta igénybevételre. Ez 
leginkább a pályára engedélyezett sebesség mértékében ölt testet. Amennyiben az adott vasúti szakasz állapotában kedvezőtlen változás áll be, a hálózat üzemeltetője a pálya helyreállításáig, a további állapotromlását megakadályozandó, sebességkorlátozást vezet be. Ez olykor jelentős mértékú is lehet (például 160 helyett $60 \mathrm{~km} / \mathrm{h}$ sebesség alkalmazása), ami természetesen hatással van a menetidőre. A hosszabb menetidő csak rövid ideig tolerálható, mert negatív externáliát okoz, ezért az infrastruktúra kezelőjétől elvárható az eredeti állapot mihamarabbi visszaállítása. A vasúti pálya állapotát ezért rendszeresen ellenőrizni kell és a szükséges javítási, karbantartási munkákat időben el kell végezni. Új beruházások esetén el kell érni, hogy a védelmi követelmények is megjelenjenek a tervezési és kivitelezési kritériumok között (LÉVAI Zs. 2020).

A szakemberek már 1995-ben a pályák átbocsátóképességének fokozásában látták a vasúti infrastruktúra katonai felkészítésének egyik kulcselemét (DuCHAJ I.-HoRváTH A. 1995), ami gyakorlatilag a kétvágányú vasútvonalak hosszának növelésével lehetséges. A másik fontos felkészítési kérdés a nagyfolyami hidak helyettesíthetôsége, amire külön pontban térek ki.

\section{Üzemeltetés}

A közlekedési támogatási rendszerben az üzemeltetés a vasút területén két fontos mozzanatot takar: egyrészt a közlekedési infrastruktúra üzemeltetését, másrészt a vonatforgalom lebonyolítását a vasúti hálózaton.

A közlekedési infrastruktúra üzemeltetése a pályahálózat múködtetőjének a feladata. Ebből a szempontból a vasúti pályákat kétfélék lehetnek: nyílt hozzáférésú vasútvonalak és saját célú vasúti pályák. Nyílt hozzáférésú vonalakat Magyarországon a MÁV Zrt. és a GySEV Zrt. üzemeltet. Saját célú vasúti pályát építhet az, akinek vasúti áruforgalma olyan nagy, hogy érdemes ezért külön pályát építenie. Ezek a vasúti szaknyelvben iparvágányoknak nevezett pályák valamelyik vasútállomásról vagy kiágazástól a cégek telephelyeire vezetnek. Egyes bázisainak megfelelő kiszolgálására a honvédség is rendelkezik ilyen iparvágányokkal. Üzemeltetésük, azaz a vasúti forgalom lebonyolíthatóságának biztosítása az adott cég feladata, a katonai iparvágányok tekintetében a Magyar Honvédségé.

Az üzemeltetés másik alapvető feltétele a pályák megfeleló állapotban tartása. A karbantartás nem csak a vágányokra, hanem a pálya tartozékaira is ki kell terjedjen. A vasúti számozási rendszer ismertetésekor már megjegyeztem, hogy a tájékozódást nagymértékben segítheti a vasúti pálya szelvényszámozásának ismerete. Ez azonban nem sokat ér, ha a szelvénykövek elhanyagoltak, lekopott róluk a festék, a számok rosszul láthatók. Az utóbbi időkben a festett számokat felváltották a fényvisszaverő kivitelben készült számlapok, így a láthatóság nagymértékben javult.

A vasúti pályákon a vonatforgalom lebonyolítása történhet helyhez kötött és hordozható jelzőeszközökkel adott parancsokkal, szóbeli és írásbeli utasításokkal (LÉvAI Zs. 2020). Az üzemeltetés ilyen formáját normál üzemi körülménynek nevezzük, azonban ilyen eset nem mindenkor áll fenn. A forgalmi személyzetnek képesnek kell lenni a vonatforgalom lebonyolítására rendkívüli üzemi helyzetben, azaz üzemzavarok, meghibásodások, balesetek előfordulása esetén is. Ezért szükséges volt olyan szabályok kidolgozása, amelyek megteremtik a vonatforgalom lebonyolításának lehetôségét rendkívüli körülmények között is. A jelzési és forgalmi utasítások szabályainak megfelelő ismerete e tekintetben megkérdőjelezhetetlen.

\section{Technikai oltalmazás}

Már a Bevezetésben is utaltam rá, hogy a vasúti pályák többségét a kritikus közlekedési infrastruktúra-elemek közé soroljuk. Szinte valamennyi állami és közösségi felfogás 
abból indul ki, hogy a létfontosságú infrastruktúrák közé azokat az elemeket és alrendszereket lehet sorolni, amelyeknek valamilyen rendkívüli eseményhez kapcsolható kiesése emberi életek elvesztésével járhat, gazdasági hátrányokat és anyagi károkat okozhat, valamint fennakadásokat a társadalom mindennapjaiban és a közigazgatásban (LÉvAI Zs. 2019).

Éppen ezért a vasúti pályákat meg kell védeni ellenséges támadástól vagy terrorcselekménytől. Jelen tanulmányban a földrajzi szempontból is kritikus infrastruktúra-elemek szükséges védelmét szeretném kiemelni. Ilyenek a nagyfolyami hidak, az alagutak, illetve a nagyobb vasúti csomópontok, ahol jelentős személy- és áruforgalom összpontosul.

A technikai oltalmazás nem csak a vasúti pályák védelmét jelenti, hanem olyan szabályrendszer kidolgozását is, amely lehetôvé teszi a vonatforgalom lebonyolítását rombolás esetén is, illetve annak betartása képes megakadályozni bizonyos, ártó jellegú cselekményeket. Ezen kívül a védekezésnek reagálnia kell napjaink legújabb terrorista módszerére, a kiberterrorizmusra (LÉVAI Zs. 2019).

\section{Helyreállítás}

Mint említettem, a vasúthálózat egyes elemeinek kiesése gazdasági károkat is okoz. Az újjáépítés költségei nemzetgazdasági forrásokat vonhatnak el, a forgalom kiesése következtében bevételtől esik el a hálózat üzemeltetője, a fuvarozók és a fuvaroztatók is. Ugyanez igaz a katonai közlekedési rendszerre is, tetézve azzal, hogy a pályák kiesésével az ország védelmi rendszere is sérül.

Ezért fontos a sérült vasúti vonalszakaszok mihamarabbi helyreállítása, hogy a megszakadt szállítási folyamatok újraindulhassanak, illetve a szükséges kapacitás ismét rendelkezésre álljon. A helyreállításnak nem feltétlenül kell teljes körűnek lennie. Ilyen esetekben az időtényezô nem hagyható figyelmen kívül, ezért elegendő, ha a forgalom csökkentett kapacitással rövid idő után újra tud indulni. Például egy kétvágányú pályát ért rombolás után a vonatok már az egyik vágány ideiglenes helyreállítása után csökkentett sebességgel újra tudnak közlekedni, a felsővezetéki rendszert ért kár esetén a forgalom dízelmozdonyokkal is fenntartható stb. A vasútépítési technika ma már képes arra, hogy a károkat gyorsan, ún. provizóriumok beépítésével ideiglenesen enyhítse, így a forgalom kapacitás-korlátozásokkal ugyan, de a károkozás után röviddel megindulhat.

Az alagutak és nagyfolyami hidak helyreállítása már bonyolultabb feladat. Az alagutak tekintetében provizórium nem használható, hiszen az több kilométer vasúti pálya építését jelentené adott hegyet kikerülve vagy - a már ismertetett vonalkifejtést alkalmazva magán a hegyen keresztül.

A nagyfolyami hidak esetében a helyzet ennél kedvezőbb. Értekezésében SzÁszi G. (2013) bemutatja az uszályhidak alkalmazásának lehetőségét (2. kép), ugyanakkor megemlíti, hogy használatának feltételei hazánkban nem adottak.

\section{A vasúti infrastruktúra-elemek helyettesíthetőségének földrajzi kérdései}

A technikai oltalmazás feladatai közé tartozik, hogy a vasútvonalakon a szállítás lehetősége folyamatosan biztosított legyen, azonban ez terrorcselekmények, illetve természeti csapások következtében csorbát szenvedhet. A vasútvonalak helyettesíthetőségi kérdéseire választ adhat a vasútvonalak matematikai alapú modellezése, ugyanakkor foglalkozni kell egyes különleges infrastruktúra-elemek helyettesíthetôségével, azok hálózaton belüli kiemelt szerepe miatt. 


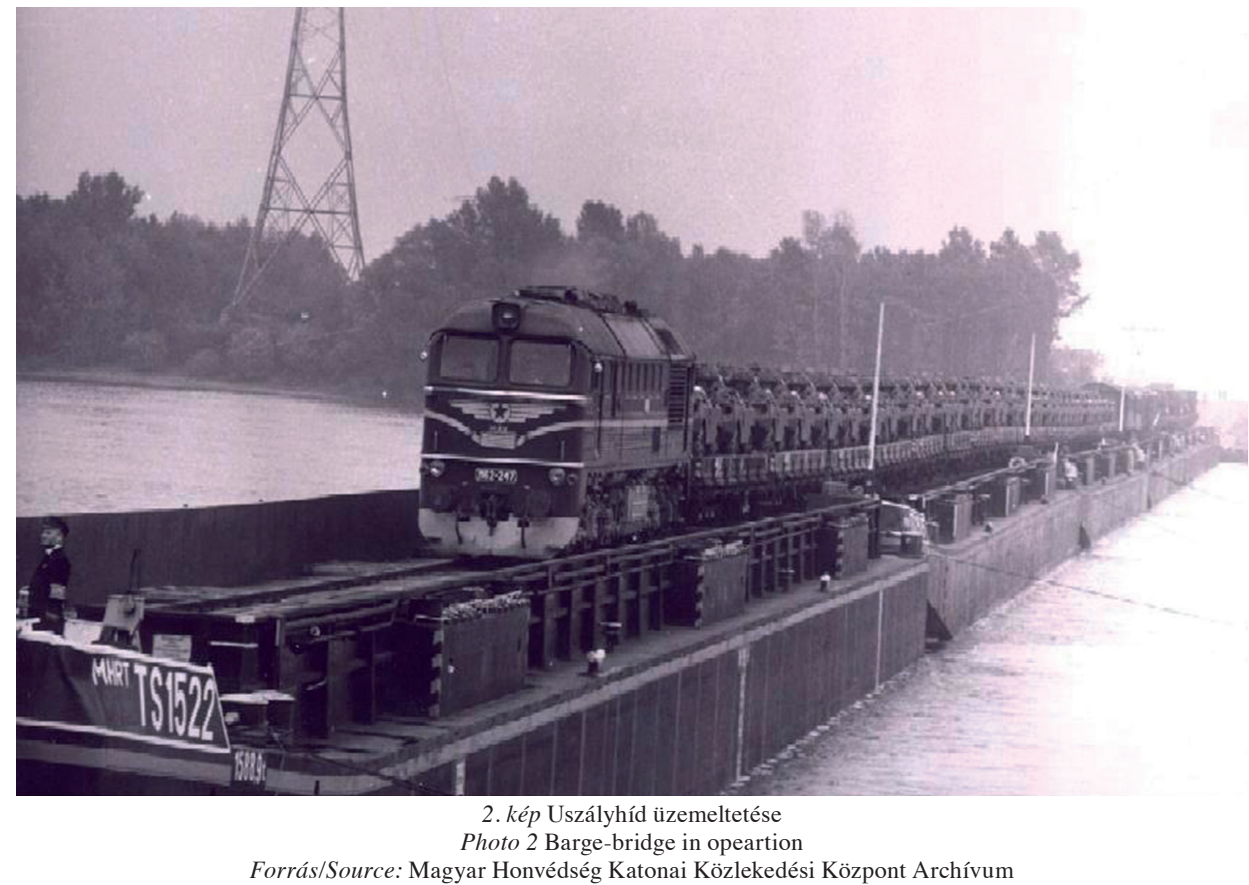

A vasúti hálózat gráf alapú megközelítése

A magyarországi vasúthálózat leírható gráfelméleti modellek segítségével. Ennek eredményeit Tóтн B. (2017, 2018, 2019) munkáiból és KerÉNYI L.-TóTH B. (2020) közleményéből ismerhetjük meg. A modell szerint meghatározott állomások jelentik a gráf csúcsait, míg a nyílt vonal (állomásközök) és a többi állomás a gráf éleit. Az állomások között különbséget kell tennünk funkciójuk szerint. Vannak olyan állomások, ahonnan több vasútvonal indul ki, azaz elágazóállomások (csomópontok) és vannak olyanok, amelyek csak egy vasútvonalon fekszenek, azaz középállomások. A gráf csúcsait az elágazóállomások jelentik, a középállomások ugyanazon él mentén helyezkednek el, így a modell szempontjából nincs jelentôségük. Meg kell említeni azonban, hogy vasútüzemi szempontból természetesen van jelentőségük, ugyanis a gráf egy élének sérülése esetén a forgalom adott állomásig fenntartható, így nem kell az egész él forgalmát korlátozni.

A gráfelméleti megközelítés fontossága a hálózat zavarainak feloldásában rejlik. A vasúti infrastruktúra szállítási kapacitása révén nemzetgazdasági fontosságú, azonban ezt a feladatát csak múködő hálózaton tudja ellátni. A hálózat egy elemének (állomásnak, állomásköznek) a kiesése zavart okoz a forgalom lebonyolításában, ami extrém esetben akár országrészek vasúti forgalmát is megbéníthatja, és jelentős károkat okoz a nemzetgazdaságnak.

A gráfelméleti modell segítségével a zavar bekövetkezésének pillanatában rendelkezésre állhatnak a szükséges kerülő útirányok, amelyek képesek az adott forgalom levezetésére, így a szükséges intézkedések meghozatala gyorsabb, a keletkező károk mértéke kisebb. Ez katonai szempontból kiemelten fontos, hiszen a vasúti pályák rombolása esetén az utánpótlási vonalak elvágásával az ország védelmi képessége jelentősen csökken, ezért a haderő hadászati és hadmúveleti mozgékonyságának biztosításához elengedhetetlen a közlekedési támogatás folyamatosságának fenntartása. 
Mint említettem, az alagutak és a nagyfolyami hidak újjáépítése időigényes feladat, és provizóriumokkal sem igen pótolhatók, ezért ezekben az esetekben a helyettesítést a kerülő útirányok jelentik. Földrajzi szempontból ilyennek tekintjük a Duna- és Tisza-hidakat (1. és 2. táblázat), illetve a vasúti alagutakat (3. táblázat).

1. táblázat - Table 1

Magyarország vasúti Duna-hídjai

Rail-bridges over the Danube in Hungary

\begin{tabular}{|c|c|c|c|c|}
\hline Állomásköz & $\begin{array}{l}\text { Vágányok } \\
\text { száma }\end{array}$ & $\begin{array}{c}\text { Vontatási } \\
\text { nem }\end{array}$ & Vasútvonal & Megjegyzés \\
\hline $\begin{array}{l}\text { Komárom } \\
\text {-Révkomárom }\end{array}$ & 1 & villamos & $\begin{array}{l}\text { Komárom } \\
\text {-Révkomárom }\end{array}$ & $\begin{array}{l}\text { közvetlen kapcsolat } \\
\text { Szlovákiával }\end{array}$ \\
\hline $\begin{array}{l}\text { Angyalföld } \\
\text {-Obuda }\end{array}$ & 1 & villamos & $\begin{array}{l}\text { Budapest } \\
\text {-Esztergom }\end{array}$ & Északi összekötő híd \\
\hline $\begin{array}{l}\text { Ferencváros } \\
\text {-Budapest-Kelenföld }\end{array}$ & 2 & villamos & $\begin{array}{l}\text { Budapest } \\
\text {-Hegyeshalom }\end{array}$ & Déli összekötő híd \\
\hline Pörböly-Baja & 1 & dízel & $\begin{array}{l}\text { Bátaszék } \\
\text {-Kiskunhalas }\end{array}$ & $\begin{array}{l}\text { közös közúti-vasúti } \\
\text { híd }\end{array}$ \\
\hline
\end{tabular}

Forrás/Source: saját szerkesztés/own editing

2. táblázat-Table 2

Magyarország vasúti Tisza-hídjai

Rail-bridges over the Tisza in Hungary

\begin{tabular}{|c|c|c|c|c|}
\hline Állomásköz & $\begin{array}{l}\text { Vágányok } \\
\text { száma }\end{array}$ & $\begin{array}{c}\text { Vontatási } \\
\text { nem }\end{array}$ & Vasútvonal & Megjegyzés \\
\hline $\begin{array}{l}\text { Eperjeske } \\
\text {-Bátyú }\end{array}$ & 1 & dízel & Tuzsér-Bátyú & $\begin{array}{l}\text { fonódó szakasz, közvet- } \\
\text { len kapcsolat Ukrajnával }\end{array}$ \\
\hline Záhony-Csap & 1 & dízel & Záhony-Csap & $\begin{array}{l}\text { fonódó szakasz, közvet- } \\
\text { len kapcsolat Ukrajnával }\end{array}$ \\
\hline Tokaj-Rakamaz & 1 & villamos & $\begin{array}{l}\text { Miskolc } \\
\text {-Nyíregyháza }\end{array}$ & \\
\hline $\begin{array}{l}\text { Poroszló } \\
\text {-Tiszafüred }\end{array}$ & 1 & dízel & $\begin{array}{l}\text { Füzesabony } \\
\text {-Debrecen }\end{array}$ & \\
\hline $\begin{array}{l}\text { Kisköre } \\
\text {-Abádszalók }\end{array}$ & 1 & dízel & $\begin{array}{l}\text { Kál-Kápolna } \\
\text {-Kisújszállás }\end{array}$ & közös közúti-vasúti híd \\
\hline Szolnok-Szajol & 2 & villamos & $\begin{array}{l}\text { Budapest- } \\
\text { Debrecen-Záhony }\end{array}$ & \\
\hline $\begin{array}{l}\text { Lakitelek } \\
\text {-Tiszaug }\end{array}$ & 1 & dízel & $\begin{array}{l}\text { Lakitelek } \\
\text {-Kunszentmárton }\end{array}$ & \\
\hline $\begin{array}{l}\text { Csongrád } \\
\text {-Szentes }\end{array}$ & 1 & dízel & $\begin{array}{l}\text { Kiskunfélegyháza } \\
\text {-Szentes }\end{array}$ & \\
\hline $\begin{array}{l}\text { Algyő-Hód- } \\
\text { mezővásárhely }\end{array}$ & 1 & $\begin{array}{c}\text { dízel } \\
\text { /villamos }\end{array}$ & $\begin{array}{l}\text { Szeged } \\
\text {-Békéscsaba }\end{array}$ & tram-train híd \\
\hline
\end{tabular}

Forrás/Source: saját szerkesztés/own editing 
Magyarország vasúti alagútjai

Rail-tunnels in Hungary

\begin{tabular}{llcc}
\hline Vasútvonal & Alagút & Hossz $(\mathbf{m})$ & Az építés éve \\
\hline Budapest-Esztergom & Piliscsaba & 780 & 1895 \\
Győr-Veszprém & Olaszfalu & 242 & 1896 \\
& Porva-Csesznek I & 31 & 1896 \\
& Porva-Csesznek II & 37 & 1896 \\
& Porva-Csesznek III & 110 & 1896 \\
Zalaegerszeg-Örihódos & Nagyrákos & 375 & 2001 \\
Székesfehérvár-Tapolca & Balatonkenese & 96 & 1909 \\
Budapest-Székesfehérvár & Kis-Gellért-hegy & 361 & 1861 \\
Budapest-Pécs & Abaliget I & 667 & 1973 \\
& Abaliget II & 114 & 1979 \\
& Abaliget III & 418 & 1979 \\
Dombóvár-Bátaszék & Mócsény & 607 & 1873 \\
Aszód-Balassagyarmat & Becske & 210 & 1896 \\
Eger-Putnok & Szarvaskó I & 157 & 1908 \\
& Szarvaskó II & 76 & 1908 \\
& Sáta & 190 & 1908 \\
\hline
\end{tabular}

Forrás/Source: MÁV Zrt., saját szerkesztés/own editing

Az 1-3. táblázat adatai alapján a következő megállapítások tehetők:

- a hidak többsége egyvágányú, nem villamosított vasútvonalon fekszik;

- több híd nemzetközi vasúti kapcsolatot is biztosít;

- nagy kapacitású, kétvágányú vonal csak a Déli összekötő és a szolnoki Tisza-hídon halad keresztül;

- vannak közös, közúti-vasúti hidak is;

- a hidak közül csak három fekszik vasúti fővonalon (Déli összekötő, Szolnok, Tokaj);

- csak kevés foovonalon található alagút: a Budapest-Pécs vonalon, igaz, ott több is, illetve a nagyrákosi alagút a Zalaegerszeg-Örihódos vonalon;

- a Kis-Gellért-hegy alagútnak csak személyforgalmi jelentősége van.

A helyettesíthetôség vizsgálatakor abból kell kiindulnunk, hogy a három legfontosabb fővonali híd hogyan pótolható, ha valamely okból nem lennének járhatók. Ennek megállapítására használható a magyarországi vasútvonalak Tóтн B. (2019) által elvégzett redundancia-vizsgálata. A kelet-magyarországi vasútvonalak földrajzi elhelyezkedése olyan, hogy a Budapest-Záhony távot két vasútvonalon is meg lehet tenni: az egyik a BudapestHatvan-Miskolc-Nyíregyháza-Északi kitérő-Záhony, a másik a Budapest-SzolnokDebrecen-Nyíregyháza-Záhony útvonal. A tokaji Tisza-híd az első, a szolnoki Tisza-híd a második útvonal része. Ebből következik, hogy a két útvonal alternatívája egymásnak, azaz az egyik vasútvonal zavara esetén a forgalom a másik vonalon lebonyolítható, s a két Tisza-híd helyettesíthetősége is megoldott. Annak minimális az esélye, hogy mindkét híd egyszerre használhatatlan legyen. Ilyen esetben a tiszafüredi Tisza-hídon keresztül kerülhető ki a másik két Tisza-híd a Budapest-Hatvan-Füzesabony-Debrecen-NyíregyházaZáhony útvonalon (2. ábra). A problémát itt a Füzesabony-Debrecen egyvágányú, nem villamosított vasútvonal elégtelen kapacitása okozhatja. 


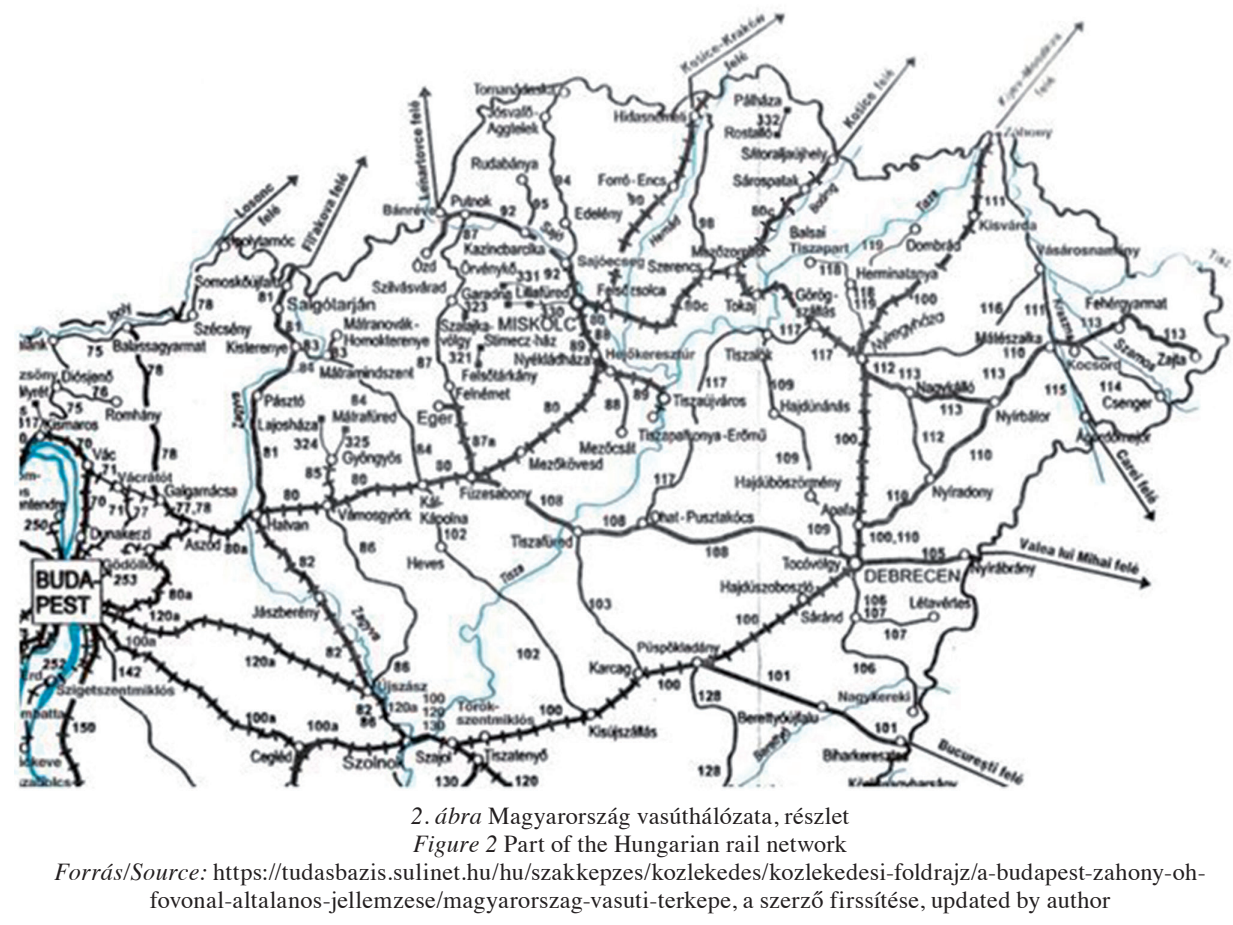

Sokkal nagyobb bajt okozna a Déli összekötő híd zavara. A kétvágányú vonalszakasz jelenleg is kapacitása határán üzemel, a háromvágányúra történő bővítés már el is kezdődött. Ugyanakkor a harmadik vágány a jelenlegi vasúti híd északi oldalán épül, tovább csökkentve a távolságot a Rákóczi-híd és a vasúti dunai átkelő között. Így egy esetleges támadás mindkét hídban károkat okozhat. A Déli összekötő híd alternatívája első gondolatra az Északi összekötő híd lehet, azonban az egyvágányú vonal a Pilisben kanyarogva dombvidéki jelleget ölt, kapacitása elégtelen nagyobb vasúti forgalom levezetésére. Az útvonal Dorog után Tokod irányába kanyarodik, majd a Duna partján haladva éri el Almásfüzitőt, ahol becsatlakozik a Budapest-Hegyeshalom fővonalba. Ez a vonal szintén egyvágányú, de már nem villamosított. A közlekedést jelentôsen nehezíti a Dorog állomáson szükségessé váló vontatójármú-csere.

A komáromi Duna-híd igénybevételéhez már szükséges egy másik ország vasúti infrastruktúrájának használata. Elvileg lehetséges a Budapest-Szob-Érsekújvár-RévkomáromKomárom útvonalon való közlekedés. A vasútvonalak végig villamosítottak, és ebben az esetben még az áramrendszerek különbözőségével sem kell számolni. A menetidőt csak az Érsekújváron és Komáromban szükséges, kétszeri menetirányváltás növeli. A közlekedés azonban bonyodalmakkal járhat, amennyiben az adott vasútvállalat nem rendelkezik Szlovákiában múködési engedéllyel, így ez az útvonal csak a Szlovákiában is menetvonal-foglalásra jogosultak részére jelenthet megoldást.

A Déli összekötő híd azonban nem csak Hegyeshalom felé biztosít összeköttetést, hanem - alternatíva híján - az egész kelet-nyugati irányú vasúti forgalom rajta halad keresztuil. Ezért a Közép- és Dél-Dunántúlra irányuló vasúti forgalom számára egyéb megoldást kell találni. Budapesttől délre már csak Bajánál található vasúti híd, amelynek igénybevétele irreálisan nagy kerüloót jelent a vonatok számára, ráadásul a vonal csaknem teljes egészé- 
ben egyvágányú pályákon vezet, így a tereléskor kapacitásproblémák léphetnek fel, illetve gondot okozhatnak a nem villamosított vonalszakaszok is.

A megoldást szükség- és épített hidak jelenthetik. A nagyfolyami vasúti átkelés szükség esetén megoldható uszályhidak alkalmazásával (2. kép). A megfelelő eljárást és technikát SzÁszi G. (2013) ismerteti, e helyütt csak annyit jegyzek meg, hogy az uszályhidak felállítása előtt a vasúti pályát a folyóparthoz kell vezetni, így vasútépítési tevékenységre mindenképpen szükség van az átkelés kialakításához (LÉvAI Zs. 2020).

Az épített hidak tekintetében javasolható a „V0” vasútvonal megépítése. A vasútvonal legfóbb célja a kelet/délnyugati teherfogalom Budapesten kívüli átvezetése. A vasútvonal részeként új Duna-hidak is épülnének, alternatívát nyújtva a Déli összekötő vasúti híd számára. A „V0” vasútvonal a teherforgalom számára épülne meg, kétvágányú, villamosított, $160 \mathrm{~km} / \mathrm{h}$ sebességre alkalmas pályaként, ugyanakkor a Déli összekötő híd kiesése esetén használhatnák személyvonatok is a két országrész között. Ebben az esetben a budapesti vonatok a Keleti pályaudvar helyett Kelenföldre vagy a Déli pályaudvarra közlekednének. A pályaudvarok városi közlekedési kapcsolatai megfelelőek (M4 és M2 metróvonal, számos busz és villamos). További alternatívaként vizsgálhatók olyan barnamezős beruházások, amelyek jelenlegi vagy volt vasútvonalak mentén teremtik meg az átkelés lehetőségét (Tóth B.-LÉVAI Zs. 2020).

A helyettesíthetőség szempontjából a többi nagyfolyami híd mellékvonalon fekszik, nincs jelentős forgalma. A fentiekből látható, hogy egyedül a Poroszló-Tiszafüred közötti hídnak lehet stratégiai szerepe. Azonban hiba lenne a hidak védelméról és karbantartásáról lemondani, mert kiesésük régiókat szigetelne el egymástól, és bizonyos esetekben szükség lehet használatukra a katonai szállítások során is.

Az alagutak helyettesítése csak a fővonalak esetében releváns. A Budapest-Pécs vonal alagútjai a Mecsek-hegységben találhatók, közel egymáshoz, kikerülésük csak nagy kerülővel lehetséges a Dombóvár-Kaposvár-Gyékényes-Barcs-Szentlőrinc-Pécs útvonalon, Gyékényesen irányváltással. Villamos vontatás csak Gyékényesig lehetséges, onnan dízelmozdonnyal lehet tovább közlekedni. Katonai szempontból fontos útvonal, ugyanis erre halad a vasútvonal Bosznia-Hercegovina felé.

A Zalaegerszeg-Ő́rihódos vonal alagútjának sérülése esetén Szlovénia felé ellehetetlenül a vasúti forgalom. A kerülőút vagy Ausztrián keresztül Szentgotthárd-Graz-Maribor, vagy pedig Horvátországon át, Gyékényes-Varasd-Csáktornya-Ormósd felé vezet. Mindkét útvonalon egy közbenső ország vasúti infrastruktúráját is használni kell, aminek problémáit a komáromi Duna-híd igénybevételével kapcsolatban említettem. Az útvonal szintén fontos katonai szempontból Olaszország, mint az egyik fó európai NATO-tagország elérése miatt.

\section{A budapesti vasúti infrastruktúra helyettesithetósége}

TóTH B (2019) redundancia-vizsgálata kimutatta, hogy a budapesti vasúti infrastruktúra egyes elemei is nagyon nehezen helyettesíthetők zavaruk vagy kiesésük esetén. A 3.ábrán a budapesti vasúthálózat kritikus szakaszait 1-től 3-ig számokkal jelöltem. A Déli összekötő vasúti hídon (1) túl az egyik ilyen vasúti vonalszakasz a bal parti körvasút Angyalföld elágazás-Rákospalota-Újpest szakasza (2), a másik pedig a külső körvasút Angyalföld elágazás-Rákosszentmihály elágazás szakasza (3).

A kettessel jelölt szakasz kizárása esetén a Budapestről Szlovákia felé irányuló, illetve a dunakanyari személyforgalmat, míg a hármassal jelölt elem kiesése esetén a Magyarországon át Szlovákiába irányuló tranzit áruforgalmat nem lehetne lebonyolítani.

Mindkét esetben szükséges kerülőút lehet a személyszállításból kivett VácrátótGalgamácsa vasútvonal. A vonal stratégiailag fontos szerepet töltött be már az 1980-as 


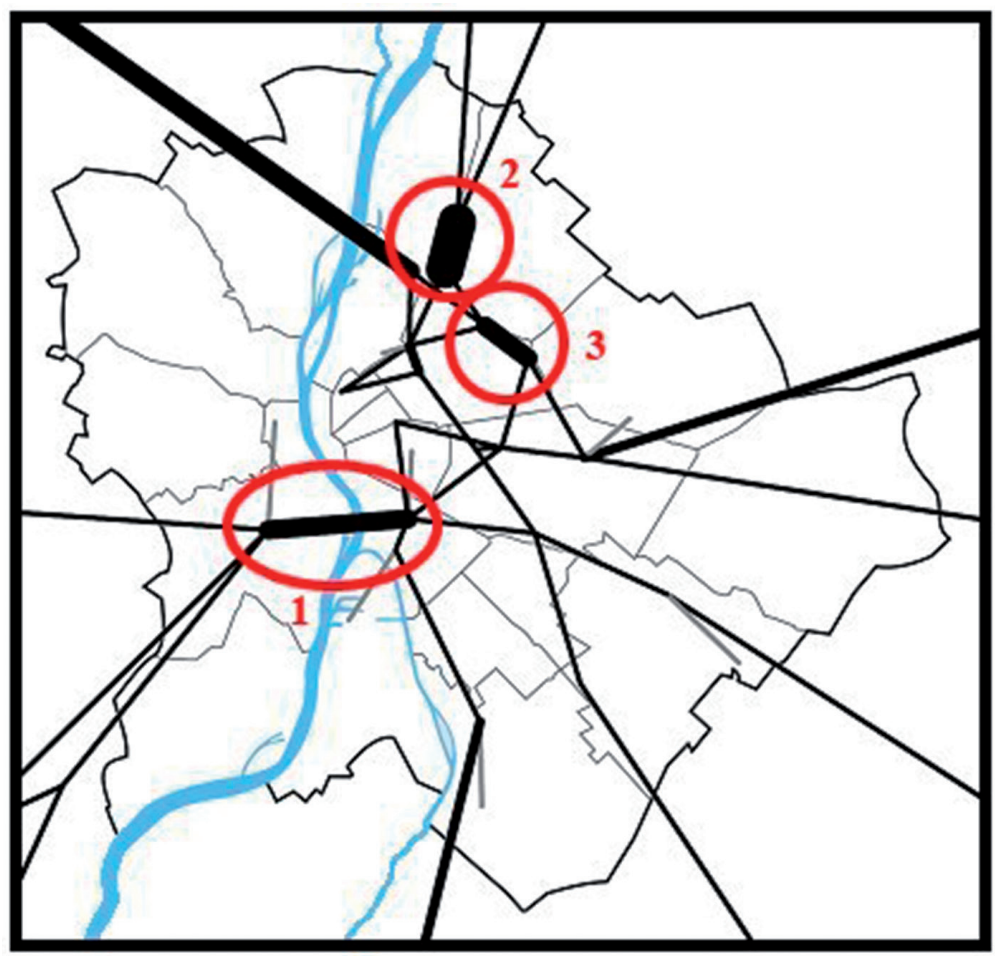

3. ábra A budapesti vasúthálózat kritikus elemei

Forrás: Tóтн B. 2019 3. ábrájának felhasználásával saját szerkesztés

Figure 3 The critical elements of rail network in Budapest

Source: own editing based on Figure 3, То́тн, В. 2019

években, még villamosították is az akkori Csehszlovákia felé irányuló, Budapestet elkerülő szállítások miatt. Ezt kihasználva javasolható a két budapesti infrastruktúra-elem kiesése esetén a Budapest-Aszód-Galgamácsa-Vácrátót-Vác-Szob útvonal. A pálya végig villamosított, Aszódig és Váctól kétvágányú, közte egyvágányú. Aszódon menetirány váltás szükséges. Problémaként merül fel a vonalon található $10 \%$-es emelkedő okozta vontathatótömeg-korlátozás a mozdonyok kapcsolókészülékének jelentős terhelése miatt, amit tolómozdonyok alkalmazásával lehet megoldani.

Ugyancsak segíthet a budapesti vasúthálózat zavarainak feloldásában a villamosított Hatvan-Újszász-Szolnok vasútvonal is. A vonal Hatvan és Újszász között egyvágányú, Újszásztól kétvágányú. Az említett két vonal a Budapestet elkerülő vasúti körgyưrú északkeleti részének tekinthetô.

A budapesti fejpályaudvarok kiesése alapvetően nehézzé teszi a vasúti személyszállítást, de egy elem kiesésétôl nem omlik össze a rendszer. A Nyugati pályaudvar keletről a Keleti pályaudvarral, Kőbánya-Kispest állomással és Zugló megállóhellyel, északról Rákospalota-Újpest állomással és Zugló megállóhellyel pótolható. A Keleti pályaudvar keletről Rákos, Kőbánya felső és Kelenföld állomásokkal, valamint Nyugati pályaudvarral, délrôl Ferencváros és Kőbánya-Kispest állomásokkal, nyugatról a Déli pályaudvarral és Kelenföld állomással helyettesíthető. A Déli pályaudvar, mivel csak Kelenföld állomással van kapcsolata, Kelenfölddel, illetve egyes vonatok Keleti pályaudvarra, valamint Kóbánya-Kispest állomásra történő irányításával pótolható. 
Több fejpályaudvar egyszerre történő kiesése már jelentős probléma elé állítaná a közlekedési alágazatot, a kapacitásszúkülés mértéke olyan nagy lenne, hogy nem lenne elegendő busz a vonatok pótlására. Ebben az esetben a fóvárosba jutást egyéni módon, esetleg korlátozásokat bevezetve kellene megoldani.

Katonai és közlekedési szempontokat is tekintve ugyancsak fontos kérdés a Liszt Ferenc repülőtér vasúti elérésének és a vasútvonalnak a helyettesíthetősége. Jelen pillanatban csak a 100a jelú vonal halad el a repülőtér mellett, amely nem megfelelő utasforgalmi kapcsolatot ad a repülőtérnek, illetve innen ágazik ki a repülőtér iparvágánya. A tervezett új, földalatti vonal adhat alternatívát a repülőtér vasúti elérésére.

\section{Összefoglalás}

Tanulmányom a katonai közlekedési támogatás rendszerén belül a vasúti közlekedés földrajzi kérdéseivel foglalkozik. A téma aktualitását a vasúti közlekedésnek a közútinál környezetbarátabb múködése adja. A fenntartható fejlődés érdekében a szállítások során várható a szektor előretörése. Mindez igaz lehet a katonai szállításokra is. Ha a vasút versenyképessége nem romlik, sőt növekszik (például a sebesség növekedésével), illetve előtérbe kerülnek a környezetkímélő szállítási módok, akkor a haderő jelentősebb hazai és kontinentális szállítási feladatait vasúttal lehet megoldani. Ezért érdemes vizsgálni, hogy a növekvő szállítási igényeknek a vasúti alágazat milyen módon képes megfelelni. Ennek egyik fontos kérdése a földrajzi tényezőkből adódó használhatóság.

Cikkem első részében bemutattam a katonai közlekedési támogatási rendszer logisztikai és földrajzi szempontú megközelítését, illetve a vasútra vonatkozó feladatait, a második részben a vasútföldrajzi tényezők figyelembevételével a feladatok megoldhatóságát elemeztem. A vizsgálat eredménye az alábbiakban foglalható össze:

- a vasúti közlekedési rendszer földrajzi szempontokat figyelembe véve képes a katonai közlekedési támogatás feladatainak ellátására;

- a katonai vasúti szállítások lebonyolítására leginkább a kétvágányú, villamosított vasútvonalak a legalkalmasabbak, ezért a szállítások tervezésekor törekedni kell ezek minél nagyobb mérvú igénybevételére;

- a szállítások optimális útvonalát gráfelméleti modellel célszerú meghatározni, és ezeket az útvonalakat előre rögzíteni;

- a vasútvonalak technikai védelme mellett fontos olyan üzemeltetési szabályrendszer kidolgozása, aminek betartása és betartatása elősegíti a védelmi feladatok megoldását, illetve sérülések esetén a vonatforgalom lebonyolítását.

A kutatás további fontos eleme volt a vasúthálózati elemek helyettesíthetôségének földrajzi elemzése. Az infrastruktúra-elemek kiesése jelentős hátrányokat okozhat az országnak, a katonai mozgási-szállítási lehetőségek szúkülése pedig nemzetbiztonsági, védelmi kérdéseket is felvet.

Javaslatokat tettem a vasútvonalak, hálózati elemek helyettesithetóségére, aminek figyelembevételével a vasúti forgalom-még ha kisebb kapacitással is-fenntartható, így a gazdasági és a katonai logisztikai feladatok elláthatók.

A bemutatott elemzés bizonyítja, hogy a haderő számára a vasútföldrajzi ismeretek előnyt jelenthetnek a katonai közlekedési támogatási feladatok megoldásában és a hadszíntér-felderítés terén.

Az ismertetett megoldások azonban nem csak a katonai szállítási feladatok megoldásához járulnak hozzá, hanem segíthetik a fuvarozó és a fuvaroztató cégeket is, hogy az infrastruktúra sérülése esetén keletkező káraikat minimalizálják. 
A javaslatok az infrastruktúra-kezelők számára is hasznosak lehetnek az egyes elemek sérülésekor bevezetendő kerülő útirányok megtervezéséhez és kijelöléséhez, valamint a személyszállítási szolgáltatások során felmerülő kerülő útirányok megtervezésekor is. Lehet, hogy nem minden esetben az autóbuszos pótlás jelenti a legkisebb kárral járó megoldást.

\author{
LÉVAI ZsOLT \\ Közlekedéstudományi Intézet, Budapest \\ NKE HHK Katonai Múszaki Doktori Iskola, Budapest \\ levai.zsolt@kti.hu
}

\title{
IRODALOM
}

BÁтнy S. 2013: Katonai logisztika. - In: PoHL Á.-SzÁsZI G. (szerk.): Közszolgálati logisztika. - Nemzeti Közszolgálati és Tankönyv Kiadó, Budapest. pp. 138-141.

DuCHAJ I.-HoRvÁTH A. 1995: Szajoli baleset katonaszemmel. - Katonai Logisztika 3. 2. pp. 225-235.

KERÉNYi L.-TóTH B. 2020: Alternatív vasúti útvonalak minősítése a magyar honvédség szállítási feladatainak ellátásában. - Katonai Logisztika 28. 1-2.pp. 79-99. DOI 10.30583/2020/1-2/079

Kress, M. 2016: Operational Logistics - The Art and Science of Sustaining Military Operations. - Springer International Publishing, Switzerland. 221 p. DOI 10.1007/978-3-319-22674-3

LÉvAI Zs. 2019: A vasúti szektor védelmi lehetőségei terrorakciók ellen. - Közlekedéstudományi Szemle 69. 5. pp. 50-71. DOI 10.24228/KTSZ.2019.5.5

LÉvAI Zs. 2020: A vasúti alágazat jelenkori kapcsolódása a közlekedési támogatás rendszeréhez. - Katonai Logisztika 28. 1-2. pp. 198-223. DOI 10.30583/2020/1-2/198

MH 2005: Magyar Honvédség Közlekedési Támogatási Doktrína. - Magyar Honvédség Közlekedési Főnökség, Budapest. 89 p.

PETE Sz. 2019: A mozgáskoordináló központ múködése a befogadó nemzeti támogatás keretén belül. - Honvédségi Szemle 147. 4. pp. 114-133.

Siposné KecsKeméthy K. 2018: Közlekedés és földrajz. - In: SiposnÉ KeCsKEMÉThy K.-SzÁszi G.: Közlekedési hálózatok. Dialóg Campus Kiadó, Budapest. pp. 11-23.

Siposné Kecskeméthy K. 2019: Katonaföldrajz szócikk. - In: Krajnc Z.-Forgács B.-GőcZe I.-Szabó J. -Szabó M. (szerk.): Hadtudományi Lexikon, Új kötet. Ludovika Egyetemi Kiadó, Budapest. pp. 522-523.

SzÁSzI G. 2013: A vasúti hálózati infrastruktúrával szemben támasztott újszerú védelmi követelmények kutatása, a továbbfejlesztés feltételrendszerének vizsgálata, doktori (PhD-) értekezés. - Nemzeti Közszolgálati Egyetem, Budapest. 182 p. DOI 10.17625/NKE.2014.028

То́тн B. 2017: Állomások és állomásközök zavarának gráfelméleti alapú vizsgálata a magyarországi vasúthálózaton. - Hadmérnök 12. 4. pp. 52-66.

Tо́тн B. 2018: Menetidő- és menetvonalhossz növekedés gráfelméleti alapú vizsgálata a magyarországi vasúthálózaton állomások és állomásközök zavara esetén. - Hadmérnök 13. 1. pp. 118-132.

То́тн B. 2019: Forgalmatlan, de nélkülözhetetlen - a magyarországi vasúthálózat redundanciavizsgálata. - In: HoRváth G.-GAÁL B.-Horváth B. (szerk.): Közlekedéstudományi Konferencia. Conference on Transport Sciences: Alternatív-Autonóm-Kooperatív Mobilitás. Széchenyi István Egyetem, Győr. pp. 550-558.

Tóth B.-LÉvAI Zs. 2020: Budapest vasúti elkerülésének barnamezős alternatívái. - In: FöLDI L. (szerk.): Szemelvények a katonai múszaki tudományok eredményeiből I. - Ludovika Egyetemi Kiadó, Budapest. (Kiadás alatt.) 